\title{
Effect of One-Step and Multi-Steps Polishing System on Enamel Roughness
}

\author{
Cynthia Sumali ${ }^{1}$, Adi Hidayat ${ }^{2}$, Joko Kusnoto ${ }^{3}$, Widijanto Sudhana ${ }^{4}$ \\ ${ }^{1}$ Postgraduate Program, Faculty of Dentistry, Trisakti University, Jakarta 11440, Indonesia \\ ${ }^{2}$ Department of Public Health, Faculty of Medicine, Trisakti University, Jakarta, 11440, Indonesia \\ ${ }^{3}$ Department of Orthodontic, Faculty of Dentistry, Trisakti University, Jakarta 11440, Indonesia \\ ${ }^{4}$ Department of Public Health, Faculty of Dentistry, Trisakti University, Jakarta 11440, Indonesia \\ Correspondence e-mail to: valkarie_cth@yahoo.com
}

\begin{abstract}
The final procedures of orthodontic treatment are bracket debonding and cleaning the remaining adhesive. Multistep polishing system is the most common method used. The disadvantage of that system is long working time, because of the stages that should be done. Therefore, dental material manufacturer make an improvement to the system, to reduce several stages into one stage only. This new system is known as one-step polishing system. Objective: To compare the effect of one-step and multi-step polishing system on enamel roughness after orthodontic bracket debonding. Methods: Randomized control trial was conducted included twenty-eight maxillary premolar randomized into two polishing system; one-step OptraPol (Ivoclar, Vivadent) and multi-step AstroPol (Ivoclar, Vivadent). After bracket debonding, the remaining adhesive on each group was cleaned by subjective polishing system for ninety seconds using low speed handpiece. The enamel roughness was subjected to profilometer, registering two roughness parameters ( $\mathrm{Ra}, \mathrm{Rz}$ ). Independent t-test was used to analyze the mean score of enamel roughness in each group. Results: There was no significant difference of enamel roughness between one-step and multi-step polishing system $(p>0.005)$. Conclusion: One-step polishing system can produce a similar enamel roughness to multi-step polishing system after bracket debonding and adhesive cleaning.
\end{abstract}

\begin{abstract}
ABSTRAK
Efek sistem poles satu tahap dan multi-tahap pada kekasaran email setelah pelepasan bracket orthodonti. Setelah perawatan orthodonti selesai, tahap pekerjaan yang harus dilakukan adalah melepaskan bracket dan membersihkan sisa-sisa bahan perekat. Metode yang sering digunakan adalah dengan membersihkan sisa perekat menggunakan sistem poles bertingkat, yang dikenal sebagai multi-step polishing system. Kekurangan sistem ini adalah lamanya waktu kerja, karena banyaknya tahap pekerjaan. Saat ini produsen material kedokteran gigi telah memperbaiki sistem ini, dengan membuat suatu sistem poles satu tahap. Sistem baru ini disebut sebagai one-step polishing system. Tujuan: Membandingkan tingkat kekasaran email setelah dilakukan debonding bracket orthodonti menggunakan one-step dan multi-step polishing system. Metode: Pemilihan dan penentuan kelompok sistem poles yang digunakan pada dua puluh delapan gigi premolar rahang atas dilakukan secara acak. Penelitian ini menggunakan one-step OpraPol (Ivoclar, Vivadent) dan multi-step AstroPol (Ivoclar, Vivadent). Setelah dilakukan debonding bracket, sisa bahan perekat dari setiap kelompok dibersihkan selama 90 detik menggunakan sistem yang telah dipilih menggunakan handpiece putaran lambat. Kekasaran email kemudian diukur menggunakan profilometer, dengan dua parameter ( $\mathrm{Ra}, \mathrm{Rz}$ ). Uji t digunakan untuk menganalisis perbedaan rerata kekasaran email dari kedua kelompok. Hasil: Tidak terdapat perbedaan bermakna pada rerata kekasaran email antara kedua sistem poles $(p>0,005)$. Simpulan: Debonding bracket dan pembersihan sisa-sisa perekat menggunakan one-step polishing system memberikan kekerasan email yang serupa dengan multi-step polishing system.
\end{abstract}

Key words: enamel surface roughness, multi-step polishing system, one-step polishing system 


\section{INTRODUCTION}

After fixed orthodontic appliance treatment, the main concern is to restore the enamel surface as close as possible to the original condition. At orthodontic bracket removal, there are two possible conditions that might be occurred. First, bond failure will occur at the adhesive-enamel interface (adhesive failure) and the second, bond failure will occur at the adhesive-bracket interface (cohesive failure). In both cases, there will be adhesive remnants left on the enamel surface, which require clean-up procedure. ${ }^{1-4}$ If remnants are not completely removed, the tooth surface will become rough. This can lead to non-aesthetic discoloration and increasing plaque retention. ${ }^{5-11}$ Therefore, many researchers have introduced different techniques of adhesive remnant removal and subsequent enamel polishing, such as scraping with scaler or adhesive remover plier, removing with a tungsten carbide bur, or the latest approaches involving Nd:YAG laser. ${ }^{12-14}$

The most common procedure in adhesive remnant removal technique uses low-speed handpiece in conjunction with sequential use of multiple polishing tools, known as multi-step polishing system. ${ }^{3,5,15,16}$ The disadvantage of this system is long working time, because of the serial stages that should be done. Therefore, dental material manufacturer make an effort to improve the system, so as to reduce serial stages into one stage only. This new system is known as one-step polishing system. Many researchers claimed that multistep polishing system could provide better result in composite polishing than other polishing techniques. ${ }^{5,15}$ On the contrary, other researchers found out that one-step polishing system can produce comparable composite polishing result to multi-step polishing system. They claimed that one-step polishing system may be a good choice for polishing composite and reduced chair time. ${ }^{17,18}$

The purpose of this study was to compare the effect of one-step and multi-step polishing system on enamel surface roughness after orthodontic bracket debonding using quantitative assessment with profilometer.

\section{METHODS}

Twenty-eight maxillary premolars, extracted for orthodontic purposes were used in this study. They were selected on the basis of visual observation using probe and loop. The inclusion criteria were no carious lesions, no cracks on buccal surfaces and were kept in saline solution. The roots of the teeth were removed and the crowns were embedded in acrylic resin blocks. The buccal surfaces were cleaned with non-fluoridated pumice, rinsed with water and air-dried. The 28 teeth were divided into two groups with randomized block design. First group will be polished using one-step polishing system (OptraPol, Ivoclar, Vivadent) and the other using multi-step polishing system (Astropol, Ivoclar, Vivadent). ${ }^{19,20}$

The pretreatment enamel surface roughness was evaluated using a profilometer, which operated under $1.25 \mathrm{~mm}$ maximum length and $0.25 \mathrm{~mm}$ cut off. This process involved registration of the following two roughness parameters, the average roughness ( $\mathrm{Ra}$ ) which describes the overall surface roughness and maximum height of the profile $(\mathrm{Rz})$ which describes the average maximum peak-to-valley height of five consecutive sampling depths. ${ }^{21}$ Two recordings were made on each specimen with the stylus contact in a perpendicular direction. The results were the averaged of the two records. Next, the buccal surfaces were etched using 37\% phosphoric acid (DiaEtch, DiaDent, Korea) for 15 seconds, rinsed with water and dried with air spray. After the etching, stainless brackets (Mini Sprint, Forestadent, Germany) were bonded. Light cured adhesive (Xenoortho, Dentsply-Sankin, Japan) was applied to the etched enamel. Excess adhesive were removed, mesial and distal side of the tooth was light-cured for 10 second.

The specimens were then stored in aquadest solution and kept in $37^{\circ} \mathrm{C}$ incubator for 24 hours. Brackets were debonded using universal testing machine. The remnant adhesive was scored using adhesive remnant index score (ARI). The remaining adhesive was cleaned using polishing system for the respective group. Both polishing systems were operated with 10,000rpm low-speed handpiece for total 90 seconds and $2 \mathrm{~N}$ force with conjunction of water cooling. After clean-up procedures were completed, final roughness parameters were registered using profilometer Mitutoyo, Japan) (Figure 1).

The amount of remaining adhesives on the enamel surface was determined using criteria Ari of Artun and Berland. The criterias were no adhesive material on the enamel (score 0), less than half of adhesive material remained on the enamel (score 1), more than half adhesive material remained (score 2) and all of the adhesive material remained on the enamel (score 3$)$. $^{3,22}$

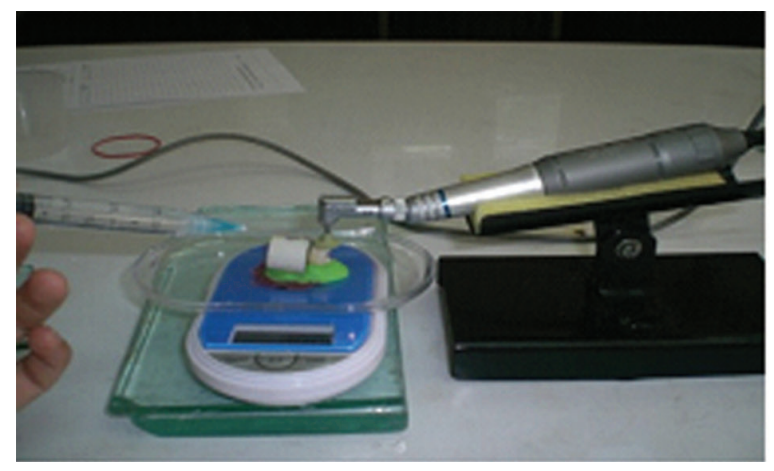

Figure 1. Polishing procedure using either one-step polishing system (OptraPol) or multi-step polishing system (Astropol) 


\section{RESULTS}

One sample Kolmogorov-Smirnov test was used to analyze the normality of surface roughness variables. This analysis showed that distribution of $\mathrm{Ra}$ and $\mathrm{Rz}$ on both groups was normal ( $p>0.05$ ). Independent t-test to the initial registration of pretreatment variable of $\mathrm{Ra}$ and $\mathrm{Rz}$ showed that the randomize can distribute variable of $\mathrm{Ra}$ and $\mathrm{Rz}$ equally to the one-step polishing system and multi-step polishing system groups $(p>0.05)$. Mean comparison of initial Ra between one-step and multi-step groups were respectively $(0.41 \pm 0.22 \mu \mathrm{m})$ and $(0.35 \pm 0.18 \mu \mathrm{m})$, mean comparison of initial $\mathrm{Rz}$ were $(2.15 \pm 1.18 \mu \mathrm{m})$ and $(1.72 \pm 0.8 \mu \mathrm{m})$ (Table 1$)$.

After bracket debonding, the remaining adhesives were determined using criteria ARI. Most of the specimens have score of 2 . The mean rank of remaining adhesives on one-step polishing system group is 13.57 and mean rank of remaining adhesive on multi-step polishing system group was 15.43. Mann-whitney analysis revealed no significant differences between groups $(p>0.05)($ Table 1).

In the one-step polishing group the pretreatment enamel surface roughness was $0.41 \pm 0.22 \mu \mathrm{m}$ and after polishing was $0.24 \pm 0.06 \mu \mathrm{m}$. In the multi-step polishing group the pretreatment enamel surface roughness was $0.346 \pm 0.179 \mu \mathrm{m}$ and after polishing was $0.23 \pm 0.08 \mu \mathrm{m}$. These results showed that the enamel surface after polishing using both one-step and multi-step polishing system were smoother than the pretreatment condition (Table 2).

So it can be said that the polishing system used in this study can restore the enamel surface back to the original pretreatment condition. Furthermore, the enamel surface roughness value after polishing was lower than the pretreatment condition. The result of surface roughness indicated no significant difference $(p>0.05)$. Ra means between one-step and multi-step polishing system were $(0.24 \pm 0.58 \mu \mathrm{m})$ and $(0.23 \pm 0.08 \mu \mathrm{m})$, respectively. Rz means between one-step and multi-step polishing system were $(1.25 \pm 0.34 \mu \mathrm{m})$ and $(1.23 \pm 0.5 \mu \mathrm{m})$, respectively. These results showed that one-step polishing system was as effective as multi-step polishing system in cleaning the remaining adhesive after orthodontic bracket debonding (Table 2).

\section{DISCUSSION}

Orthodontic treatment has an objective to achieve a better condition of teeth both functionally and esthetically. But the procedure can cause an alteration of enamel surface roughness. The alteration depends on bracket debonding and adhesive removing method. The enamel surface alteration is important since the rough enamel surface potentially risk the caries lesion. ${ }^{3,4}$

Before enamel treatment was provided, no statistically significance difference in surface roughness was noted between groups. But after the polishing of remaining adhesive using one-step polishing system and multi-step polishing system, lower Ra and $\mathrm{Rz}$ values were obtained with the use of both polishing systems $(p<0.05)$. These results showed that enamel surfaces become smoother after polishing with both systems. According to these results, our first and second hypotheses that either one-step or multi-step polishing system can influence the enamel surface roughness were accepted. Similarly, the use of composite burs for cleaning remaining adhesive after orthodontic bracket debonding also found to have similar result. ${ }^{4}$

Table 1. Mean values of enamel surface roughness before treatment $(\mu \mathrm{m})$ on one-step and multi-step polishing system

\begin{tabular}{cccc}
\hline & $\begin{array}{c}\text { One-step } \\
(\mathbf{n}=\mathbf{1 4})\end{array}$ & $\begin{array}{c}\text { Multi-step } \\
(\mathbf{n}=\mathbf{1 4})\end{array}$ & $\boldsymbol{p}$ value \\
\hline Initial Ra & $0.41 \pm 0.22$ & $0.35 \pm 0.18$ & 0.4 \\
Initial Rz & $2.153 \pm 1.185$ & $1.72 \pm 0.8$ & 0.27 \\
ARI & 13.57 & 15.43 & 0.33 \\
\hline
\end{tabular}

Table 2. Mean values of enamel surface roughness/Ra and enamel surface roughness/Rz $(\mu \mathrm{m})$ before and after one-step and multi-step polishing system after orthodontic bracket debonding

\begin{tabular}{lcccc}
\hline & $\begin{array}{c}\text { One-step } \\
(\mathbf{n}=\mathbf{1 4})\end{array}$ & $\boldsymbol{p}$ value & $\begin{array}{c}\text { Multi-step } \\
(\mathbf{n}=\mathbf{1 4})\end{array}$ & $\boldsymbol{p}$ value \\
\hline Initial Ra & $0.41 \pm 0.22$ & $* 0.000$ & $0.35 \pm 0.18$ & $* 0.000$ \\
Final Ra & $0.24 \pm 0.06$ & & $0.23 \pm 0.08$ & \\
Initial Rz & $2.153 \pm 1.185$ & $* 0.000$ & $1.722 \pm 0.082$ & $* 0.000$ \\
Final Rz & $1.251 \pm 0.342$ & & $1.229 \pm 0.501$ & \\
\hline
\end{tabular}

*significant $(p<0.05)$

After bracket debonding, the remaining adhesives were determined using criteria ARI. Most of the specimen has score 2, because of the same treatment of all specimen including type of the etch, adhesive, brackets and debonding force. However, the amount of remaining adhesive in this study actually did not have a lot of influence to the result. Since polishing instrument remain static on one area during polishing process, the measurement of surface roughness only evaluated along the working length of profilometer stylus, which was about $1.25 \mathrm{~mm}$.

The third hypothesis of this study was accepted. The enamel surface roughness after polishing with one-step and multi-step polishing system did not show significance difference. It may be caused by involvement of composition and size of particles of 
the polishing instrument structure. According to the manufacturer, one-step polishing system (OptraPol) contains premium silicone and micro-fine diamond crystals. ${ }^{19}$

This study did not measure the loss of enamel caused by the polishing procedure. In further study, it should be considered since cleaning-up the remaining adhesive after orthodontic bracket debonding has a big risk causing enamel loss. Further studies are required to study the enamel loss during polishing procedure and to discover the enamel surface roughness using qualitative assessment with scanning electron microscope (SEM).

\section{CONCLUSION}

In conclusion, both one-step and multi-step polishing system will affect the enamel surface roughness. Meanwhile there was no significant difference enamel surface roughness between one-step and multi-step polishing system after orthodontic bracket debonding.

\section{ACKNOWLEDGEMENT}

The author would like to thank the staffs of Dental Material Laboratory of the Universitas Indonesia for the use of the testing equipment and many colleagues for their help in specimen preparation.

\section{REFERENCES}

1. Bishara SE, VonWald L, Laffoon JF, Warren JJ. Effect of self-etch primer/adhesive on shear bond strength of orthodontic brackets. Am J Orthod Dentofac Orthop. 2001;119:621-4.

2. Shamsi AA, Cunningham JL, Lamey PJ, Lynch E. Shear bond strength and adhesive after orthodontic bracket bonding. Angle Orthod. 2006;6:694-9.

3. Ozer T, Basara G, Kama JD. Surface roughness of the restored enamel after orthodontic treatment. Am J Orthod Dentofacial Ortho. 2010;137:368-74.

4. Karan S, Kircelli BH, Tasdelen B. Enamel surface roughness after debonding: comparison of two different burs. Angle Orthod. 2010;80:1081-8.

5. Jung M, Eichelberger K, Klimek J. Surface geometry of four nanofiller and one hybrid composite after one-step and multi-step polishing. Oper Dent. 2007;32:347-55.

6. Cenci MS, Venturini D, Cenci TP, Piva E, Demarco FF. The effect of polishing techniques and time on the surface characteristics and sealing ability of resin composite restorations after one-year storage.
Oper Dent. 2008;33:169-76.

7. Ahn BJ, Ahn SJ, Lee SJ, Kim TW, Nahm DS. Analysis of surface free energy characteristics of various orthodontic materials. Am J Orthod Dentofac Orthop. 2009; 136:668-74.

8. Karamouzos A, Athanasiou AE, Papadopoulos MA, Kolokithas G. Tooth color assesment after orthodontic treatment: a prospective clinical trial. Am J Orthod Dentofac Orthop. 2010;138:537.e1-8.

9. Craig RG, Powers JM, Wataha JC. Dental materials: properties and manipulation. St Louis: Elsevier Mosby; 2004.

10. Kidd EAM, Smith B G N, Pickard HM. Pickard's Manual of operative dentistry. 7th ed. New York: Oxford University Press; 1996.

11. Powers J M, Wataha JC. Dental materials properties and manipulation. 9th ed. St. Louis: Elsevier Mosby; 2008.

12. Campbell PM. Enamel surfaces after orthodontic bracket debonding. Angle Orthod. 1995;65:103-10.

13. Kim SS, Park WK, Son WS, Ahn HS, Ro JH, Kim YD. Enamel surface evaluation after removal of orthodontic composite remnants by intraoral sandblasting: a 3-dimensional surface profilometry study. Am J Orthod Dentofac Orthop. 2007;132:71-6.

14. Zachrisson BU. Bonding in orthodontics. In: Graber TM, Varnasdal RJ, Vig KW, editors. Orthodontics: current principles and techniques. 3th ed. St Louis: Elsevier Mosby; 2000. p.557-603.

15. Eliades T, Gioka C, Eliades G, Makou M. Enamel surface roughness following debonding using two resin grinding methods. Eur J Orthod. 2004;26:3338.

16. Ergucu Z, Turkun LS, Aladag A. Color stability of nanocomposites polished with one-step systems. Oper Dent. 2008;33:413-20.

17. Korkmaz Y, Ozel E, Attar N, Aksoy G. The influence of one-step polishing systems on the surface roughness and microhardness of nanocomposites. Oper Dent. 2008;33:44-50.

18. Watanabe T, Miyazaki M, Takamizawa T, Kurokawa H, Rikuta A, Ando S. Influence of polishing duration on surface roughness of resin composites. J. Oral Sci. 2005;47:21-5.

19. Ivoclar Vivadent [Internet]. Liechtenstein: Bendererstrasse; c2011 [updated 2010; cited 2010 Nov 21]. Optrapol. Available from http://www.ivoclarvivadent.com/en/all/products/clinical-accessoriesinstruments/polishing-systems/optrapol.

20. Ivoclar Vivadent [Internet]. Liechtenstein: Bendererstrasse; c2011 [updated 2010; cited 2010 Nov 21]. Astropol. Available from http://www.ivoclarvivadent.com/en/all/products/clinical-accessoriesinstruments/polishing-systems/astropol. 
21. Mitutoyo. Surface Roughness Tester: User's Manual. Tokyo. 2000;178:14-25.

22. Northrup RG, Berzins DW, Bradley TG, Schuuckit W. Shear bond strength comparison between two orthodontic adhesives and self-ligating and conventional brackets. Am J Orthod Dentofac Orthop. 2007;77:701-6. 